logical work. Mrs. B. Rothwell rendered invaluable computational assistance.

\section{REFERENCES}

Aird, I., Bentall, H. H., Mehigan, J. A., and Roberts, J. A. F. (1954). Brit. med. F., 2,315 .

Ball, P. A. J. (1962). Ibid., 2, 948.

Blegvad, B. (1960). Dan. med. Bull., 7, 72.

Brown, D. A. P., Melrose, A. G., and Wallace, J. (1956). Brit. med. F., 2, 135 .

Clark, D. H. (1953). Ibid., 1, 1254.

Clarke, C. A., Edwards, J. W., Haddock, D. R. W., Howel-Evans, A. W., McConnell, R. B., and Sheppard, P. M. (1956). Ibid., 2, 725.

Evans, D. A. P., McConnell, R. B., and Sheppard, P. M. (1959). Ibid., 1, 603 .

Cox, A. J. (1952). Arch. Path., 54, 407.

Craig, J. D. (1948). Brit. med. 7., 2,330

Doll, R., Drane, H., and Newell, A. C. (1961). Gut, 2, 352. and Kellock, T. D. (19s1). Ann. Eugen. (Lond.), 16, 231 Swynnerton, B. F., and Newell, A. C. (1960). Gut, 1, 31 . Bvans, D. A. P. (1963). Personal communication.
Goidsenhoven, G. van, Wilkoff, L., and Kirsner, J. B. (1958), Gastroenterology, 34, 421.

Hanley, W. B. (1963). M.D. Thesis, University of Liverpool.

Hirschowitz, B. I. (1955). 7. Lab. clin. Med., 46, 568.

Kay, A. W. (1953). Brit. med. ₹., 2, 77.

Køster, K. H., Sindrup, E., and Seele, V. (1955). Lancet, 2, 52.

Marks, I. N., and Shay, H. (1959). Ibid., 1, 1107.

Mirsky, I. A., Futterman, P., Kaplan, S., and Broh-Kahn, R. H. (1952). 7. Lab. clin. Med., 40, i7.

Niederman, J. C., Gilbert, E. C., and Spiro, H. M. (1962). Ann. intern. Med., 56, 564 .

Oiha, K. N., and Wood, D. R. (1950). Brit. F. Pharmacol., 5, 389.

Purohit, G. L., and Shukla, K. C. (1960). Indian ₹. med. Sci., 14, 522.

Race, R. R., and Sanger, R. (1962). Blood Groups in Man, 4th ed. Blackwell, Oxford.

Roberts, J. A. F. (1957). Brit. f. prev. soc. Med., 11, 107.

Ronsky, R., and Skala, I. (1961). Z. Vitamin-, Hormon- u. Fermentforsch., 11, 273.

Sievers, M. L. (1959). Amer. 7. Med., 27, 246.

- and Fischer, G. L. (1957). Amer. F. dig. Dis., 2, 363

Spiro, H. M., Ryan, A. E., and Jones, C. M. (1956). Gastroenterology, 30, 563.

Ventzke, L. E., and Grossman, M. I. (1962). Ibid., 42, 292.

\title{
Gastric Secretion in Hyperthyroidism
}

\author{
M. J. WILLIAMS,* M.R.C.P. ; D. W. BLAIR, † CH.M., F.R.C.S.ED.
}

As early as 1904 Miesowicz noted impaired secretion of acid by the stomach in patients with hyperthyroidism. Since then many studies of gastric secretion in such patients have been undertaken, and a high incidence of achlorhydria has been reported (Moll and Scott, 1927 ; Brown, 1930 ; Lerman and Means, 1932 ; Berryhill and Williams, 1932 ; Wilkinson, 1933 ; Louis and Wills, 1937 ; McElroy et al., 1938 ; Brown et al., 1941). The relative incidence ranged from $12 \%$ (McElroy et al., 1938) to $68 \%$ (Berryhill and Williams, 1932) and hypochlorhydria was frequent in those not achlorhydic. As in most cases acid secretion returned or increased after treatment (Berryhill and Williams, 1932; Wilkinson, 1933; Louis and Wills, 1937), a functional change in the gastric mucosa, possibly related to overactivity of the sympathetic nervous system, was suggested as the cause of impaired acid secretion. No consistent relationship was found between the presence or absence of achlorhydria and the age of the patients or the severity of the disease, but it was thought to be more frequent in those with symptoms of longer duration (Moll and Scott, 1927 ; Wilkinson, 1933 ; Louis and Wills, 1937).

The stimulus to gastric secretion used in these studies was either some variety of test meal and/or conventional doses of histamine, all of which provide inadequate stimulation of the parietal cells (Card et al., 1955 ; Card and Sircus, 1958). The true incidence of achlorhydria in hyperthyroidism cannot therefore be assessed from these previous observations, and, using the augmented histamine test (Kay, 1953), Card and Sircus (1958) stated that no alteration in gastric secretion was found in hyperthyroid patients, but no details were given. More recently Bock and Witts (1963) reported a detailed study of gastric secretion in hyperthyroidism and reached similar conclusions. They initially performed the azuresin ("diagnex") test on 18 patients and then carried out more detailed studies with the augmented histamine test in a further 29. Achlorhydria was found only once in the 47 patients, and the mean total acid output in the 29 patients studied with the augmented histamine test was no different from that reported by Card and Sircus (1960) for normal subjects. In some of their patients,

* Lecturer in Therapeutics, University of Aberdeen.

+ Senior Lecturer in Surgery, University of Aberdeen. however, acid secretion increased after treatment, and they suggested that active thyrotoxicosis inhibited the secretory response of the stomach. They also studied gastric biopsies from 36 patients. The majority showed no abnormality, but there was superficial gastritis in $8(22 \%)$ and atrophic gastritis in $3(8 \%)$.

During the past 18 months we have also used the augmented histamine test to study gastric secretion in hyperthyroidism, being interested in the observed low incidence of peptic ulceration in patients with this condition (Hinton, 1932; Ivy et al., 1950 ; Crile, 1951). Basal acid and pepsin secretions have also been estimated and gastric biopsies were taken in a number of the patients. Our findings differ in several respects from those of Bock and Witts (1963).

\section{Material and Methods}

The ages of the 32 patients (27 females, 5 males) studied ranged from 20 to 63 (mean 45). None had coincident gastrointestinal disease. The diagnosis of hyperthyroidism was confirmed in all cases by discriminant tests of thyroid function, including the clinical diagnostic index (Crooks et al., 1959), estimation of the serum P.B.I. (Farrell and Richmond 1961), and standard radioiodine studies using either ${ }^{131} \mathrm{I}$ or ${ }^{132} \mathrm{I}$. The duration of symptoms was obtained from the patient's history, and the clinical diagnostic index was used as a quantitative measure of severity. ${ }^{1}$ This index has previously been shown to correlate well with other measures of severity such as the B.M.R. and results of radioiodine studies (Crooks et al., 1959).

The haemoglobin was measured in all cases and serum was examined for thyroid autoantibodies by standard techniques to detect coincident autoimmune thyroiditis. The following results were considered significant: precipitin test positive $(+)$ in any titre; tanned-red-cell test if titre was greater than $1 / 25,000$. Lower titres were ignored, as were complement-

${ }^{1}$ Clinical Diagnostic Index : Each symptom and sign in hyperthyroidism is allotted a numerical value and the aggregate score in the individual
case is termed the clinical diagnostic index. The score can also be case is termed the clinical diagnostic index. The score can also be
used in toxic subjects as an index of severity. The original article used in toxic subjects as an index of severity. The original article
should be consulted for full details of the method (Crooks et al., 1959). 
fixing antibodies which are commonly found with clinically unimportant focal thyroiditis (Doniach and Roitt, 1961).

Gastric secretion was studied, using the augmented histamine test (Kay, 1953) according to the method of Card and Marks (1960).

After an overnight fast a Levin tube was passed and its tip positioned in the pyloric antrum under radiological control. The stomach was then emptied and basal secretion collected for one hour. Midway through this period mepyramine maleate ("anthisan ") 50-100 mg. was injected intramuscularly, and at the end of the basal collection histamine acid phosphate, $0.04 \mathrm{mg}$. $/ \mathrm{kg}$. body weight, was injected subcutaneously. Gastric secretion was then collected for a further hour, usually as four 15-minute specimens. Continuous suction with an electric pump was used to collect the gastric juice, the patency of the aspirating tube being ensured by the frequent injection of air. When the volumes aspirated were small, continuous handsuction replaced the use of the electric pump.

The volumes of all specimens were measured and aliquots taken, after filtering through glass-wool, for determination of pH, " total acidity," and pepsin concentration.

The $p H$ was measured either electrometrically or with indicator paper (B.D.H. narrow range) and the "total acidity" determined by titration with $\mathrm{N} / 50 \mathrm{NaOH}$, using phenolphthalein as indicator. Total acid output was then calculated as $\mathrm{mEq}$ of $\mathrm{HCl}$ (total acidity $\times$ volume). Pepsin concentration was measured by the method of Hunt (1948) and the output estimated.

Achlorhydria was considered to be present when the $p H$ never fell below 6 after maximal histamine stimulation (Card and Sircus, 1960), and in such cases the total acid output was recorded as $0 \mathrm{mEq}$.

Gastric biopsies were obtained in eight patients, using the Crosby capsule (Crosby and Kugler, 1957). The biopsy specimens were fixed in formol-saline and examined histologically after staining with haematoxylin and eosin. The appearances were classified according to the criteria of Wynn Williams et al. (1957).

All cases were studied during the period of initial investigation before any specific treatment had been given. In nine patients the augmented histamine test was repeated after treatment.

The results of the augmented histamine test in female patients have been compared with those of a "normal" group of 16 female subjects examined simultaneously. Their ages ranged from 19 to 56 (mean 42), and none had evidence of thyroid or gastro-intestinal disease.

\section{Results}

The relevant clinical and laboratory data in the hyperthyroid patients are shown in Table I.

\section{Acid Secretion}

(1) Basal Acid Secretion.-The results for the hyperthyroid patients and our normal subjects are summarized in Table II and compared with other reported normal values. The mean basal acid secretion in the hyperthyroid males was $0.85 \mathrm{mEq}$, which is well below that reported for normal male subjects. The corresponding mean for hyperthyroid females was 1.33 $\mathrm{mEq}$, or almost half that found in our normal series. This difference was highly significant $(P<0.001)$. The results for our own normal females were no different from those found by Dotevall (1961) $(\mathrm{P}>0.1)$.

(2) Maximal Acid Output.-Achlorhydria was found in five patients (four females and one male) following maximum histamine stimulation. In a further two patients only 1 and 0.8 $\mathrm{mEq} \mathrm{HCl}$ respectively was secreted, but in both the $\mathrm{pH}$ fell to
TABLE I.-Gastric Secretion and Other Data in 32 Patients with

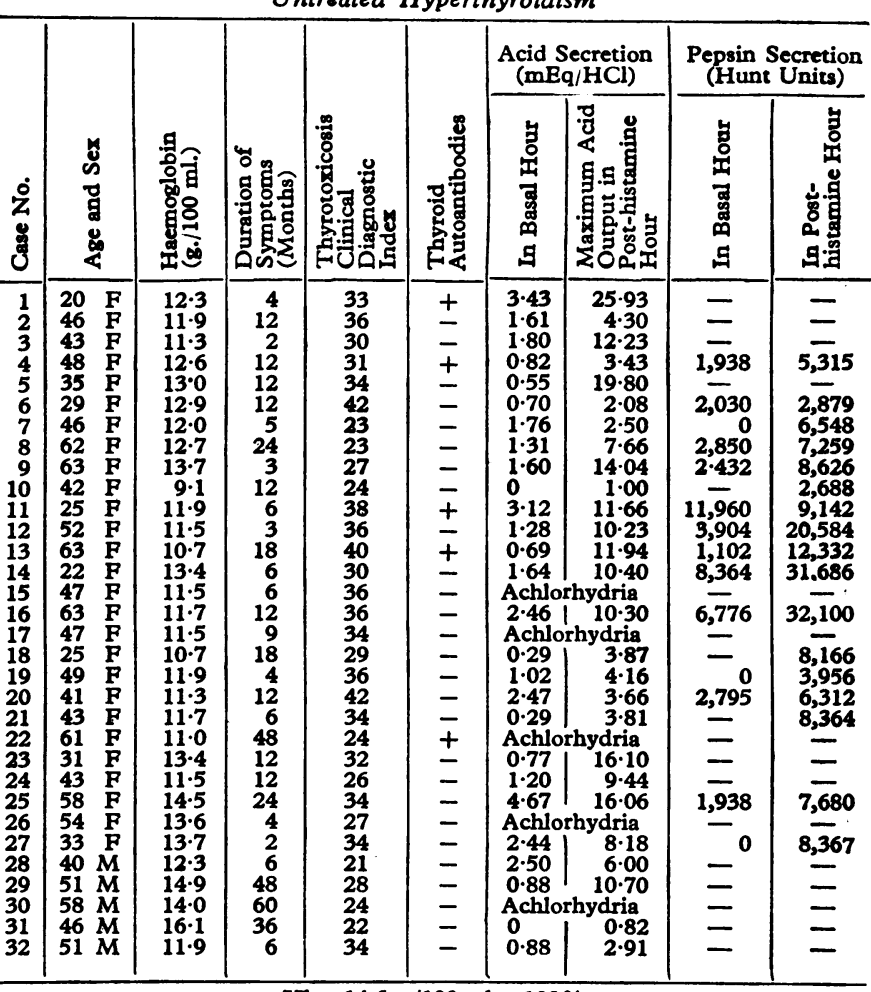

$\mathrm{Hb}: 14 \cdot 6 \mathrm{~g} . / 100 \mathrm{ml} .=100 \%$.

2.5. The range and mean acid outputs in both sexes are shown in Table III and compared with the corresponding values for normal subjects. The mean acid output for hyperthyroid males was $4.09 \mathrm{mEq} \mathrm{HCl}$, which is well below that reported in normals. In the hyperthyroid females the mean acid output was higher at $7.88 \mathrm{mEq} \mathrm{HCl}$, but still approximately half that found in normal subjects. In our own normal females the mean acid output was $13.93 \mathrm{mEq} \mathrm{HCl}$, which is lower than that reported by others, but when compared with the findings of Dotevall (1961) the difference was not significant $(P<0.1>0.05)$. The results in the hyperthyroid females, however, differed significantly from both our own $(P<0.01>0.001)$ and Dotevall's normal subjects $(P<0.001)$.

\section{Pepsin Secretion}

Pepsin secretion was determined in a number of the hyperthyroid females both under basal conditions and after histamine injection. The results are summarized in Table IV and compared with the findings for normal females in this hospital (C. G. Clark, personal communication, 1963). Pepsin values were considered only in samples of $\mathrm{HCl}$ concentration greater than $10 \mathrm{mEq} / 1$, as values in specimens of less acid concentration are unacceptable (Hunt, 1960).

The range of values in both groups was very wide and, although the mean basal pepsin secrętion in the hyperthyroid females was almost half that found in the controls, the difference was not significant $(P>0.1)$. After histamine injection, pepsin secretion was markedly increased, the mean for hyperthyroid females being 10,970 Hunt units and 22,080 Hunt units in controls. This difference is significant $(P<0.01>0.001)$, and as the mean volumes in the two groups were similar this presumably represents a true difference in pepsin concentration.

\section{Histology of Gastric Mucosa}

Specimens of gastric mucosa were obtained from eight hyperthyroid patients. The pathological findings are shown in Table $\mathrm{V}$ with the corresponding maximal acid outputs. 
In two patients the appearances were normal but the others showed either superficial gastritis (two cases) or atrophic gastritis (four cases). There was fairly close agreement between the histological findings and the acid secretory response. Of the four patients with atrophic gastritis three had achlorhydria, globin in this patient was $11 \mathrm{~g} . / 100 \mathrm{ml}$., but marrow examination showed only normoblastic hyperplasia with evidence of iron deficiency, and the anaemia responded fully to oral iron therapy. She was the only patient with achlorhydria whose serum showed significant titres of thyroid autoantibodies. Four others (Cases

TABLE II.-Basal Acid Secretion in Patients with Hyperthyroidism and Normal Subjects

\begin{tabular}{|c|c|c|c|c|c|c|c|c|c|}
\hline & & \multicolumn{4}{|c|}{ Females } & \multicolumn{4}{|c|}{ Males } \\
\hline & & \multirow{2}{*}{ No. } & \multirow{2}{*}{ Mean Age } & \multicolumn{2}{|c|}{$\mathrm{mEq} \mathrm{HCl}$ in Basal Hour } & \multirow{2}{*}{ No. } & \multirow{2}{*}{ Mean Age } & \multicolumn{2}{|c|}{$\mathrm{mEq} \mathrm{HCl}$ in Basal Hour } \\
\hline & & & & Range & Mean (S.D.) & & & Range & Mean (S.D.) \\
\hline Hyperthyroidism .. & .. & 27 & 44 & $0-4 \cdot 67$ & $1.33(1.18)$ & 5 & 49 & $0-2.5$ & $0.85(1.02)$ \\
\hline $\begin{array}{l}\text { Normal subiects : } \\
\text { Present series } \\
\text { Dotevall (1961) . } \\
\text { Marks et al. (1963) }\end{array}$ & .. & $\begin{array}{l}16 \\
12 \\
26\end{array}$ & $\begin{array}{l}42 \\
36.5 \\
-\end{array}$ & $\begin{array}{r}0.22-6.60 \\
0 . \overline{0-10.0}\end{array}$ & $\begin{array}{l}2.36(2.11) \\
2.24(1.76) \\
1.80\end{array}$ & $\begin{array}{l}\overline{30} \\
35\end{array}$ & 36.5 & $0-\overline{15} \cdot 0$ & $\begin{array}{l}3.70 \overline{(2} \cdot 12) \\
4.20\end{array}$ \\
\hline
\end{tabular}

TABLE III.-Maximal Acid Output in Patients with Hyperthyroidism and Normal Subjects

\begin{tabular}{|c|c|c|c|c|c|c|c|c|}
\hline & \multicolumn{4}{|c|}{ Females } & \multicolumn{4}{|c|}{ Males } \\
\hline & \multirow{2}{*}{ No. } & \multirow{2}{*}{ Mean Age } & \multicolumn{2}{|c|}{$\mathrm{mEq} \mathrm{HCl}$ in Post-histamine Hour } & \multirow{2}{*}{ No. } & \multirow{2}{*}{ Mean Age } & \multicolumn{2}{|c|}{$\mathrm{mEq} \mathrm{HCl}$ in Post-histamine Hour } \\
\hline & & & Range & Mean (S.D.) & & & Range & Mean (S.D.) \\
\hline 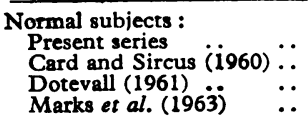 & $\begin{array}{l}16 \\
28 \\
12 \\
26\end{array}$ & $\frac{42}{36.5}$ & $\begin{array}{l}7.07-20 \cdot 50 \\
6 \cdot 20-34 \cdot 60 \\
0 \cdot 1-30 \cdot 0\end{array}$ & $\begin{array}{l}13.93(4.89) \\
17.20 \\
17.70(5.40) \\
15.20\end{array}$ & $\begin{array}{l}\overline{29} \\
24 \\
35\end{array}$ & $\frac{7}{36.5}$ & $\begin{array}{l}10 \cdot \overline{1-41} \cdot 5 \\
0 \cdot 1-50 \cdot 0\end{array}$ & $\begin{array}{l}22 \cdot \overline{65} \\
23.30 \\
22 \cdot 60\end{array}$ \\
\hline
\end{tabular}

TABLE IV.-Pepsin Secretion in Hyperthyroid Patients and in Normals

\begin{tabular}{|c|c|c|c|c|c|c|c|c|c|c|}
\hline & \multicolumn{5}{|c|}{ Basal Pepsin Secretion } & \multicolumn{5}{|c|}{ Post-histamine Pepsin Secretion } \\
\hline & \multirow{2}{*}{ No. } & \multirow{2}{*}{$\begin{array}{c}\text { Mean } \\
\text { Age }\end{array}$} & \multirow{2}{*}{$\begin{array}{c}\text { Mean } \\
\text { Vol. (m1.) }\end{array}$} & \multicolumn{2}{|c|}{$\begin{array}{l}\text { Hunt Units in Basal } \\
\text { Hour }\end{array}$} & \multirow{2}{*}{ No. } & \multirow{2}{*}{$\underset{\text { Age }}{\text { Mean }}$} & \multirow{2}{*}{$\begin{array}{c}\text { Mean } \\
\text { Vol. (ml.) }\end{array}$} & \multicolumn{2}{|c|}{$\begin{array}{c}\text { Hunt Units in } \\
\text { Post-histamine Hour }\end{array}$} \\
\hline & & & & Range & Mean (S.D.) & & & & Range & Mean (S.D.) \\
\hline
\end{tabular}

while the remaining one secreted only $0.82 \mathrm{mEq} \mathrm{HCl}$. One of the patients showing superficial gastritis secreted only 3.43 $\mathrm{mEq} \mathrm{HCl}$, but in the other the acid output was normal, as it was in the two patients with normal mucosal appearances.

Cellular infiltration was marked in five specimens, two showing superficial gastritis and three atrophic gastritis. In the remaining specimen showing atrophic gastritis, cellular infiltration was only moderate. Plasma cells and lymphocytes were always predominant and lymph-follicle formation was notable in five of the six cases (see Fig.).

\section{Correlation of Acid Output with Clinical and Laboratory Findings}

Significant anaemia $(\mathrm{Hb}<11.5 \mathrm{~g} . / 100 \mathrm{ml}$.) was present in six patients, only one (Case 22) having achlorhydria. The haemo-

TABLE V.-Gastric Mucosal Appearances in Hyperthyroidism

\begin{tabular}{|c|c|c|c|c|c|}
\hline \multirow{2}{*}{$\begin{array}{l}\text { Case } \\
\text { No. }\end{array}$} & \multirow{2}{*}{$\begin{array}{c}\text { Max. Acid } \\
\text { Output } \\
\text { (mEq HCl) }\end{array}$} & \multicolumn{4}{|c|}{ Histological Findings } \\
\hline & & $\begin{array}{c}\text { Gross } \\
\text { Appearances }\end{array}$ & $\begin{array}{c}\text { Cell } \\
\text { Infiltration }\end{array}$ & $\begin{array}{l}\text { Cell Types } \\
\text { Involved }\end{array}$ & $\begin{array}{l}\text { Lymph-Follicle } \\
\text { Formation }\end{array}$ \\
\hline 4 & $3 \cdot 43$ & Superficial & ++ & $\mathrm{P}++, \mathrm{L}+$ & + \\
\hline 12 & $\begin{array}{l}10.23 \\
11.94\end{array}$ & Normal & 二 & 一 & $=$ \\
\hline 22 & Achlorhydria & Atrophic & $\overline{+}$ & $\overline{\mathrm{P}+}$ & 三 \\
\hline 25 & 16.06 & $\begin{array}{c}\text { Superficial } \\
\text { gastritis }\end{array}$ & ++ & $\mathbf{P}++, \mathbf{L}+$ & + \\
\hline 26 & Achlorhydria & $\begin{array}{l}\text { Atrophic } \\
\text { gastritis }\end{array}$ & ++ & $\mathbf{P}++, \mathbf{L}+$ & + \\
\hline $\begin{array}{l}30 \\
31\end{array}$ & 0.82 & " & $\begin{array}{l}+t \\
+t\end{array}$ & $\begin{array}{l}\mathrm{P}++, \mathrm{L}+ \\
\mathrm{P}++, \mathrm{L}+\end{array}$ & $\stackrel{+}{+}$ \\
\hline
\end{tabular}

$1,4,11$, and 13 ) had thyroid autoantibodies, the respective acid outputs being $25.93,3.43,11.66$, and $11.94 \mathrm{mEq}$.

No evidence was found that the reduction in acid secretion in the hyperthyroid females was related to either the severity or the duration of the disease. Male patients were excluded from analysis in view of their small number.

Using the clinical diagnostic index as a guide to severity, the mean acid output in patients with an index between 20 and 30 (moderate toxicity) was $6.11 \mathrm{mEq}$, and in those with an index over 30 (severe toxicity) $8.92 \mathrm{mEq}$, this difference not being

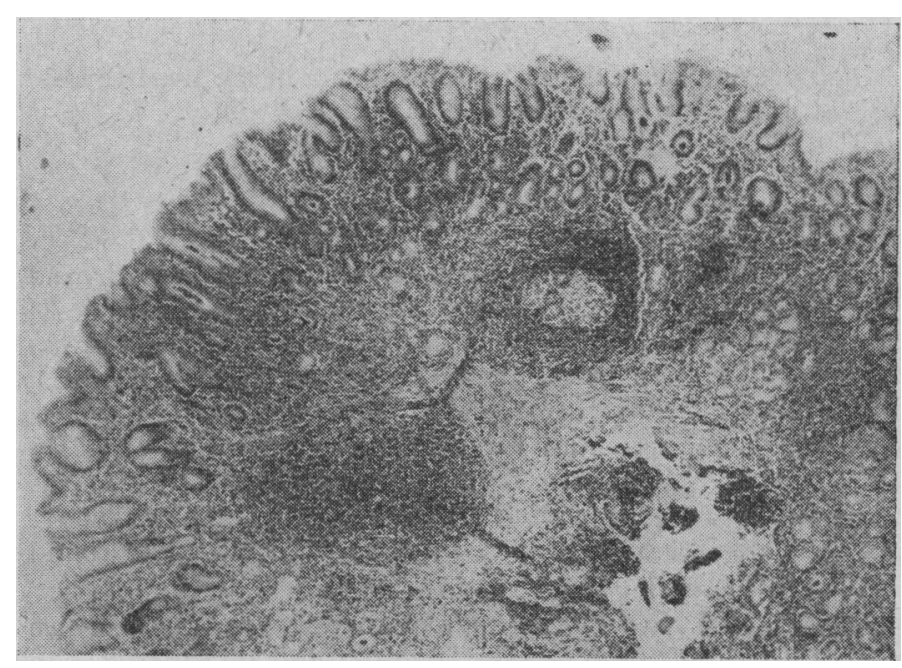

Case 31. Gastric biopsy. Atrophic gastritis with marked round-cell infiltration and lymph-follicle formation. $(\times 36$. 
significant $(P>0.1)$. With regard to duration of disease, the cases were divided arbitrarily according to whether the duration of symptoms was more or was less than one year. The mean acid outputs for the respective groups were 7.83 and $7.93 \mathrm{mEq}$.

The age of the hyperthyroid patients appears, however, to influence the acid-secretory response, and all the patients with achlorhydria were over the age of 45 . The age distribution of the hyperthyroid females permitted a convenient division into three groups-20-39 years, 40-56 years, and 57 and over. The first two groups were compared with the normal subjects divided similarly, but as none of the normal subjects were over the age of 57 the third group is unmatched. The findings for the different age-groups are shown in Table VI. In age-group 20-39 no significant difference was found between the normal and hyperthyroid patients $(P>0.1)$, but there was a significant difference between the corresponding groups in the age-range 40-56 $(\mathrm{P}<0.001)$. In the latter age-group the mean acid output for the hyperthyroid patients was only $4.21 \mathrm{mEq}$, but three patients with achlorhydria were included. When these were excluded the mean acid output was still only 5.48 $\mathrm{mEq}$, and the difference remained significant $(P<0.001)$. In the patients over the age of 57 the mean acid output was considerably higher at $10 \mathrm{mEq}$, which is significantly different from the mean in the previous age-group $(P<0.02>0.01)$ but does not differ from that found in those aged 20-39 ( $P>0.1$ ).

TABLE VI.-Influence of Age on Acid Output in Normal Female Subjects and Female Patients with Hyperthyroidism

\begin{tabular}{|c|c|c|c|c|c|}
\hline \multirow{2}{*}{$\underset{\text { group }}{\text { Age- }}$} & & \multirow{2}{*}{$\begin{array}{c}\text { No. of } \\
\text { Patients }\end{array}$} & \multirow{2}{*}{$\begin{array}{c}\text { Mean } \\
\text { Age }\end{array}$} & \multicolumn{2}{|c|}{$\begin{array}{c}\text { Maximum Acid Output } \\
(\mathrm{MEq} \mathrm{HCl})\end{array}$} \\
\hline & & & & Range & Mean (S.D.) \\
\hline $\left.\begin{array}{c}20-39 \\
40-56 \\
57+\end{array}\right\}$ & $\begin{array}{l}\text { Normal } \\
\text { Hyperthyroidism } \\
\text { Normal } \\
\text { Hyperthyroidism } \\
\text { Hyperthyroidism }\end{array}$ & $\begin{array}{r}6 \\
88 \\
10 \\
13 \\
6\end{array}$ & $\begin{array}{l}31 \\
27 \\
48 \\
46 \\
61\end{array}$ & $\begin{array}{l}7 \cdot 85-19 \cdot 75 \\
2 \cdot 08-25 \cdot 93 \\
7 \cdot 07-20 \cdot 50 \\
0.00-12 \cdot 23 \\
0.00-16 \cdot 06\end{array}$ & $\begin{array}{r}15 \cdot 16(5.29) \\
12.25(8.03) \\
13.19(4.76) \\
4.21(4.03) \\
10.00(5.69)\end{array}$ \\
\hline
\end{tabular}

The mean acid outputs in the two age-groups of normal subjects were statistically similar $(P>0.1)$.

\section{Effect of Treatment of Hyperthyroidism on Acid Output}

The augmented histamine test was repeated in nine patients after specific therapy had been given. The methods of treatment, the interval between tests, and the results are shown in Table VII. At the time of the second test six patients were euthyroid, but two had become slightly hypothyroid and one was still slightly hyperthyroid. Thyroid status was confirmed in all cases by estimation of the serum protein-bound iodine.

TABLE VII.-Effect of Treatment on Acid Output in Hyperthyroidism

\begin{tabular}{|c|c|c|c|c|c|}
\hline \multirow{2}{*}{$\begin{array}{l}\text { Case } \\
\text { No. }\end{array}$} & \multirow{2}{*}{$\begin{array}{l}\text { Method } \\
\text { of } \\
\text { Treatment }\end{array}$} & \multirow{2}{*}{$\begin{array}{c}\text { Interval } \\
\text { between } \\
\text { Tests } \\
\text { (Months) }\end{array}$} & \multirow{2}{*}{$\begin{array}{l}\text { Thyroid Status } \\
\text { at Time of } \\
\text { Repeat Test }\end{array}$} & \multicolumn{2}{|c|}{$\begin{array}{c}\text { Maximum Acid Output } \\
(\mathrm{mEq} \mathrm{HCl})\end{array}$} \\
\hline & & & & $\begin{array}{c}\text { Before } \\
\text { Treatment }\end{array}$ & $\begin{array}{c}\text { After } \\
\text { Treatment }\end{array}$ \\
\hline 1 & Antithyroid drugs & 8 & Slightly & 25.93 & $16 \cdot 45$ \\
\hline 8 & Radioiodine & 5 & Slightly & $7 \cdot 66$ & $4 \cdot 21$ \\
\hline 9 & " & 8 & Euthyroid & 14.04 & $8 \cdot 29$ \\
\hline 13 & $\begin{array}{c}\text { Antithyroid drugs } \\
\text { + surgery }\end{array}$ & $\begin{array}{r}10 \\
4\end{array}$ & Slightly & $\begin{array}{r}1.00 \\
11.94\end{array}$ & $\begin{array}{l}9 \cdot 20 \\
8 \cdot 45\end{array}$ \\
\hline 18 & Antithyroid drugs & 4 & Euthyroid & $3 \cdot 87$ & 4.99 \\
\hline 20 & Radioiodine & 3 & $"$ & 3.66 & $6 \cdot 84$ \\
\hline 28 & " " & 3 & " & $\begin{array}{r}16 \cdot 06 \\
6.00\end{array}$ & $\begin{array}{l}14.69 \\
10 \cdot 48\end{array}$ \\
\hline \multicolumn{4}{|c|}{ Mean acid outputs } & $10 \cdot 01$ & $9 \cdot 27$ \\
\hline
\end{tabular}

Considerable variation in acid-secretory response was found, four patients showing an increase and five a decrease in acid secretion. There was, however, no difference between the means of the two tests.

\section{Discussion}

Using the augmented histamine test, we found a marked reduction in gastric secretion in our patients with hyperthyroidism, and achlorhydria was present in no fewer than five $(15.6 \%)$ cases. In female patients the mean acid output was almost half that found in normal subjects, and basal acid secretion and pepsin production were also reduced. In male patients the changes were even more striking, but the number studied was too small for any definite conclusion to be reached.

The incidence of achlorhydria is lower than was found in most previous studies (Moll and Scott, 1927 ; Brown, 1930 ; Lerman and Means, 1932 ; Berryhill and Williams, 1932; Wilkinson, 1933 ; Louis and Wills, 1937 ; Brown et al., 1941), and this is almost certainly related to the more effective methods now used in the study of gastric secretion and, in particular, to the use of maximal histamine stimulation.

Our findings differ strikingly from those reported by Bock and Witts (1963), and this result is almost certainly due to a difference in the type of patients studied. If only the larger number of females are considered the mean duration of symptoms was similar for the two groups, but the age distribution of the cases was quite different. The mean age of our female patients was 44 years, with no fewer than 19 over the age of 40 , while in the Oxford series the mean age was 34 years, with only eight over 40 . We have shown that the level of acid secretion in hyperthyroidism, at least for females, bears some relation to the age of the patient, a striking reduction being observed only in the group aged 40-56. No significant reduction in acid secretion was found in our younger patients; the older patients (over 56 years) in turn showed only a slight decrease. This apparent "return" of acid secretion in the older patients discounts the effect as being simply a consequence of ageing, and no such variation was found in the normal subjects. In the light of these observations it is of interest that all our male patients, in whom the reduction in acid output was so marked, were between the ages of 40 and 58 .

The "normal" findings in the Oxford series can then be explained by their predominance of young patients, and it is of note that four of their eight patients older than 40 had a very low acid output, with achlorhydria in one. Their sole male patient over the age of 40 also secreted only $5 \mathrm{mEq} \mathrm{HCl}$. Further studies of acid secretion in both normal subjects and hyperthyroid patients in different age-groups will clearly be required before the significance of this finding can be fully assessed.

The reduction in acid secretion in hyperthyroidism was previously said to be related to some functional change in the gastric mucosa, possibly produced by sympathetic overactivity (Moll and Scott, 1927; Berryhill and Williams, 1932; Wilkinson, 1933). There is, however, no convincing evidence that sympathetic stimulation directly influences gastric secretion, but it could produce autonomic imbalance with a resultant decrease in vagal activity. Vagotomy in man regularly reduces acid secretion, both basal and maximal histamine secretion being affected (Gillespie et al., 1960). Pepsin secretion is also lowered, but only after the histamine injection, basal pepsin secretion being unaltered (Gillespie and Bowen, 1962). These changes closely resemble our findings in hyperthyroid patients, and reduced vagal activity may account for the lower acid secretion in some patients, as was suggested by Bock and Witts (1963).

A direct effect of the thyroid hormones on the gastric mucosa has also to be considered. Feeding desiccated thyroid to dogs (Truesdell, 1926 ; Nasset et al., 1959) and rats (Goldsmith and Nasset, 1959) has been found to reduce the secretion of acid by the stomach. We have also recently observed that the pure thyroid hormone, L-thyroxine, is equally effective in reducing acid secretion in rats without producing structural changes in the gastric mucosa (Blair et al., 1964). 
If, however, the reduction in acid secretion in hyperthyroidism was simply related to excess thyroid hormone, whether acting on the stomach directly or indirectly, then acid secretion should vary with the severity of the disease or its duration and should increase with treatment. Impaired secretion of acid was thought to be more frequent in patients with disease of long duration (Moll and Scott, 1927; Wilkinson, 1933 ; Louis and Wills, 1937), but our results fail to substantiate this, and the severity of the disease also appears to be without influence. We were also unable to demonstrate any consistent change in acid secretion in nine patients after treatment. It therefore appears unlikely that the marked reduction in gastric secretion observed can be directly related to the hyperthyroid state, and study of the gastric mucosal appearances suggests an alternative explanation. Only a small number of gastric biopsies were obtained, but the mucosal appearances correlated well with the reduction in acid secretion. Of four cases showing atrophic gastritis, achlorhydria was present in three and the remaining patients secreted only $0.8 \mathrm{mEq} \mathrm{HCl}$. Lesser degrees of gastritis were also found, and the observations of Siurala and Lamberg (1959) suggest that this is not uncommon in hyperthyroidism, particularly in older patients.

In those of our cases with abnormal mucosal appearances, round-cell infiltration was usually prominent and lymph-follicle formation was often noted. Similar changes are found in the gastric mucosa of some patients with untreated pernicious anaemia (Joske et al., 1955), and because of the resemblance to the histological picture of autoimmune thyroiditis an autoimmune basis for pernicious anaemia was suggested (Taylor, 1959). This has now been confirmed, complement-fixing antibodies to gastric mucosa being present in a large proportion of these patients (Irvine et al., 1962 ; Taylor et al., 1962 ; Doniach et al., 1963). These gastric cytoplasmic antibodies are specifically directed against parietal cells and are quite distinct from the various thyroid antibodies (Taylor et al., 1962). Similar gastric antibodies are, however, found in significant incidence in patients with thyroid disease (Doniach et al., 1963 ; Irvine, 1963) and are probably related to the changes in gastric mucosal structure and acid secretion which we observed. Such an immunological basis could explain the notable incidence of low acid secretion in the age-group 40-56, this being the usual age of development of " autoimmune diseases." The lack of correlation between the acid secretory response and the thyroid status is also in keeping with this hypothesis. Such a process of gradual destruction of the gastric mucosa could also lead to loss of intrinsic-factor production, accounting for the increased incidence of pernicious anaemia in patients with past or present thyrotoxicosis (Tudhope and Wilson, 1960 ; McNicol, 1961 ; Bock and Witts, 1963).

Further studies of gastric secretion in hyperthyroidism are clearly required, the findings being correlated with the presence or absence of gastric antibodies. Study of relatives of patients with hyperthyroidism might also be of interest in view of the alleged genetic aspects of autoimmunity (Hall et al., 1962).

\section{Summary}

Gastric secretion has been studied in 32 patients with hyperthyroidism, using the augmented histamine test.

Achlorhydria was found in five patients. The mean levels of basal and post-histamine acid secretion were considerably reduced as compared with normal subjects. Post-histamine pepsin secretion was also impaired. No correlation was found between the reduction in acid secretion and the severity or duration of the disease. Acid secretion was markedly lowered, however, only in middle-aged patients.

A small number of gastric biopsies were studied. Varying degrees of gastritis were found which correlated with the reduction in acid output. Cellular infiltration and lymph-follicle formation were also striking. The possibility of the changes in gastric secretion having an immunological basis is discussed.

All the patients studied were under the care of Professor A. G. Macgregor and Dr. J. Crooks, and we wish to thank them and Professor George Smith for the interest they have shown in this work. We also thank Dr. G. Scott for advice on the interpretation of the gastric biopsies and the staff of the radiology department for their help.

\section{REFERENCES}

Berryhill, W. R., and Williams, H. A. (1932). F. clin. Invest., 11, 753. Blair, D. W., Carr, J., and Williams, M. J. (1964). In preparation. Bock, O. A. A., and Witts, L. J. (1963). Brit. med. f., 2, 20.

Brown, A. (1930). Ann. Surg., 92, 321

Brown, R. B., Pendergrass, E. P., and Burdick, E. D. (1941). Surg. Gynec. Obstet., 73, 766.

Card, W. I., Marks, I. N., and Sircus, W. (1955). F. Physiol. (Lond.), 130, $18 \mathrm{P}$. (1960). Clin. Sci., 19, 147.

and Sircus, $W$. (1958). In Modern Trends in Gastroenterology, 2nd series, edited by F. Avery Jones, p. 177. Butterworth, London. (1960). Quoted by A. W. M. Smith, I. W. Delamore, and A. Wynn Williams, Gut, 1961, 2, 163. Crile, G. (1951). Quoted by A. L. Garbat, f. Mt. Sinai Hosp., 1951, 17,

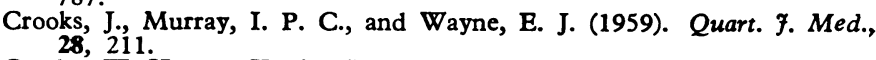

Crosby, W. H., and Kugler, H. W. (1957). Amer. F. dig. Dis., 2, 236. (1961). In Modern Trends in Endocrinology, 2nd series, edited by H. Gardiner-Hill, p. 278. Butterworth, London.

Dotevall, and Taylor, K. B. (1963). Brit. med. F., 1, 1374.

Dotevall, G. (1961). Acta med. scand., 170, 59

Farrell, L. P., and Richmond, M. H. (1961). Clin. chim. Acta, 6, 620.

Gillespie, I. E., and Bowen, D. J. (1962). Gut, 3, 255.

- Clark, D. H., Kay, A. W., and Tankel, H. I.' (1960). Gastroentero$\log y, 38,361$.

Goldsmith, D. P. J., and Nasset, E. S. (1959). Amer. F. Physiol., 197, 1. Hall, R., Saxena, K. M., and Owen, S. G. (1962). Lancet, 2, 1291.

Hinton, J. W. (1932). F. Amer. med. Ass., 98, 1702.

Hunt, J. N. (1948). Biochem. F., 42, 104.

Hunt, J. N. (1948). Biochem. F., 42, 104.

Irvine, W. J. (1963). In The Thyroid and its Diseases, edited by A. Stuart Mason, p. 129. Pitman, London.

Davies, S. H., Delamore, I. W., and Wynn Williams, A. (1962). Brit. med. f., i, 454. Ivy, A. C., Grossman, M. I., and Bachrach, W. H. (1950). In Peptic

Joske, R. A., Finckh, E. S., and Wood, I. J. (1955). Quart. F. Med., 24,

Kay, A. W. (1953). Brit. med. ₹., 2, 77.

Lerman, J., and Means, J. H. (1932). f. clin. Invest., 11, 167.

Louis, F., and Wills, L. (1937). Quart. f. Med., 6, 353 .

McElroy, J. S., Schuman, E. B., and Ritchey, J. O. (1938). Ann. intern. Med., 12, 106.

McNicol, G. P. (1961). Amer. F. med. Sci., 241, 336.

Marks, I. N., Bank, S., Moshal, M. G., and Louw, J. H. (1963). S. Afr. 7. Surg., 1, 53 .

Miesowicz, E. (1904). Wien. klin. Wschr., 17, 1206.

Moll, H., and Scott, R. A. M. (1927). Lancet, 1, 68.

Nasset, E. S., Logan, V. W., Kelley, M. L., and Thomas, M. (1959). Amer. F. Physiol., 196, 1262 .

Siurala, M., and Lamberg, B. A. (1959). Acta med. scand., 165, 181.

Taylor, K. B. (1959). Haemat. lat. (Milano), 2, 181. (1962). Brit. med. ₹., 2, 1347.

Truesdell, C. (1926). Amer. f. Physiol., 76, 20.

Tudhope, G. R., and Wilson, G. M. (1960). Quart. F. Med., 29, 513.

Wilkinson, S. A., jun. (1933). Ұ. Amer. med. Ass., 101, 2097.

Wynn Williams, A., Edwards, F., Lewis, T. H. C., and Coghill, N. F. (1957). Brit. med. F., 1, 372. 